Martin Ouředniček,

Associate professor at Faculty of Science, Vice-dean for Geographic Departments

of Charles University,

Head of the Urban and Regional

Laboratory (URRlab)

Prague, Czech Republic

martin.ourednicek@natur.cuni.cz

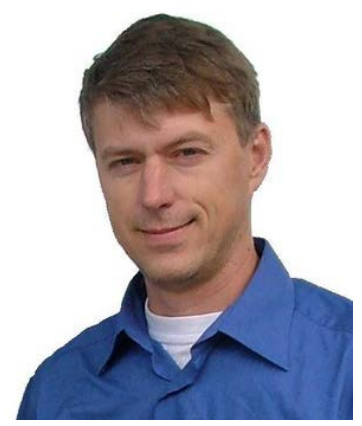

Adam Klsák,

Researcher at Department of Social

Geography and Regional Development

Charles University

Prague, Czech Republic

klsaka@natur.cuni.cz

Jiři Nemeškal,

Researcher at Department of Social

Geography and Regional Development

Charles University

Prague, Czech Republic

jiri.nemeskal@natur.cuni.cz
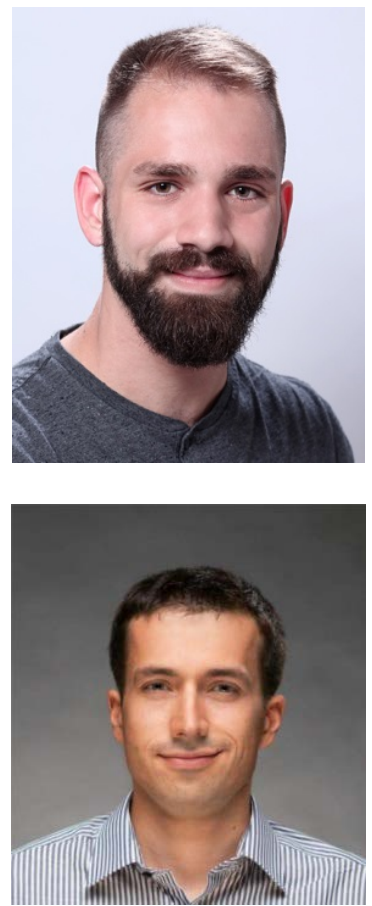

DOI 10.31554/978-5-7925-0571-1-2019-2-157-161

\title{
CZECH SUBURBANIZATION IN POST-TRANSFORMATION ERA - THE DEVELOPMENT, EVALUATION AND CHALLENGES
}

The suburbanisation process is one of the most studied issues within CEE urban studies, however, works published during the last two decades were mostly focused 
on separate case studies of individual cities [Kok, Kovács 1999; Nuissl, Rink 2005; Ouředníček 2007; Krišjāne, Bērzinšs 2012 etc.]. The comparison of the scope and intensity of suburban development on the national level lacks a common methodological approach and a generally accepted definition of the process itself. Consequently, relatively different measurements used in the case studies obstruct any rigorous comparison of the process between cities and countries. The aim of this report is to introduce a coherent methodology for the delimitation of suburban municipalities in Czechia, to describe and explain the scope and spatial distribution and to compare the development of residential suburbanisation during two periods: 1997-2008 and 2009-2016.

Keywords: suburbanization, Czechia, suburban development.

Definition of suburbanisation and suburban municipalities. Suburbanisation is defined as process of deconcentration of population and its activities from the cores of metropolitan regions to their hinterland. We focus specifically on residential suburbanisation. The change of residential environment is a crucial factor in the urbanisation process which creates tensions and gradual adaptations of the incoming population to a new physical, functional and social environment. These tensions are consequently the main topics of empirical investigation in urban geography, sociology and demography [Špačková, Ouředníček 2012]. Moreover, the inflow of new residents and new residential construction are also crucial problems for the decision-making sphere. Therefore, the character and minimal intensity of new housing construction were considered as the second factor of our definition. A suburban municipality is delimited as a place with a certain minimal level of housing construction and share of new population in-migrated from the core city. In the case of migration from the core city to the suburban hinterland there are four special migration streams according to types of housing: suburbanisation, migration to older houses, elderly migration and migration to recreational houses. All these types of migrations are relatively common within the hinterlands of Czech cities.

Methods and data. We use our own delimitation of zones of residential suburbanisation [Ouredníček, Špačková, Klsák 2018] as an analytical tool for the evaluation of positional aspects of municipalities within the Czech settlement system. The main idea of the methodological approach is to distinguish three basic types of Czech municipalities: (i) cities and towns as core source areas of suburban migration (ii), suburban municipalities and 
(iii) rural villages and small towns. Municipalities with 10,000 or more permanently resident inhabitants were selected as cores of suburban migration (total number of 130 municipalities). Then a method for the selection of suburban municipalities was developed. We employ two statistical sources, which are available at the level of municipalities and are supplied annually by the Czech Statistical Office: evidence of migration and evidence of housing construction. We used longer periods of evaluation to smooth annual variations in the case of less populous municipalities. The minimal share of migration from the core city to a municipality was set at 30 per cent in the case of one core city and 40 per cent in the case of two or three core cities. The combination of a minimal intensity of housing construction and the number of completed apartments serves as criteria for the distribution of municipalities into three zones of suburbanisation. A slightly different criterion for the threshold values of new housing construction within the first and second periods was used. We also delimitated a fourth zone containing all municipalities which met the criteria in the past. We have distinguished two different periods of suburban development: an initial phase and gradation of suburbanisation during 1997-2008 and the period of economic crisis and contemporary development during 2009-2016.

Scope and spatial distribution of residential suburbanisation. The scope of residential suburbanisation in Czechia can be measured by the absolute and relative numbers of municipalities or inhabitants living within suburban zones. It is not surprising that all the indicators grow through the evaluated periods. The structure of municipalities sorted into the three basic categories - cities, suburbs, and rural municipalities. The stable sample of core cities and the gradually growing share of municipalities within the first and second zone are pronounced. On the other hand, the number of municipalities within the third zone was increasing only till 2010 and since then has slowly fallen. Finally, the number of rural municipalities decreased by 575 units between 2008 and 2016. The population living in suburban municipalities $\left(1^{\text {st }}-3^{\text {rd }}\right.$ zones) increased from $1,314,000$ in 2008 to $1,438,000$ in 2016. We can estimate approximately one third of the population in suburban municipalities as new incomers - roughly 5 per cent of the total population of Czechia - which is a surprisingly low number. This can be derived from the share of in-migrants per 100 permanently resident inhabitants. The intensity of in-migration to suburbs is gradually increasing from 28 per mille 
in 1997-2008 to 37 per mille in the 2009-2016 period, and the intensity is very high especially within the first zone (more than 50 per mille). Thus, the suburbanisation process is far from ended and will no doubt play a significant role in the future.

Suburbanisation is a relatively widespread process, which hit not only capital city and regional centres, but literally every small town within Czechia. All 130 selected core centres of suburbanisation display a spatial connection to at least one suburban municipality which fulfilled the criteria of housing construction and share of in-coming population. Fragmentation of the settlement system and especially the system of master planning with stricter control of housing construction inside administrative boundaries of cities and less control and knowledge about core planning principles within the smaller adjacent municipalities are definitely among the main factors in such development. However, the spatial distribution of suburbanisation is far from uniform in pattern. Economic development within the successful and unsuccessful urban regions significantly influences purchasing power, housing construction and deconcentration tendencies in cities of similar population size. During the 2000s all cities and towns had their own satellite settlement, whereas now many smaller cores are surrounded only by municipalities categorised as the $4^{\text {th }}$ zone. While the suburbanisation during the 2000s could be described as a spread of suburbanisation due to hierarchical and neighbourhood diffusion, spatial development during the 2010s has the reverse character, i.e. contraction or concentration of suburban development to selected municipalities located closer to regional centres. Suburban construction and migration around smaller towns have almost disappeared. It seems that suburbanisation has reached spatial limits and new housing construction will not expand to more distant settlements. However, other processes of suburban development and also counterurbanisation processes are likely to increase in the near future.

Conclusion. According to our methodology, a total number of 1,182 suburban municipalities in Czechia were identified. In 20161.4 million inhabitants lived in the suburbs most affected by the suburbanisation process. Approximately, one third of them have moved from the core city, therefore 5 per cent of the total population of Czechia could be classified as suburbanites. This number seems to be relatively low compared for example to the USA [Johnson, Shifferd 2016]. Unfortunately, similar comparison within Europe is not available. The analysis of residential suburbanisation 
during the two selected periods - 1997-2008 and 2009-2016 - shows relatively significant changes in spatial patterns of suburban development. Generally, this can be explained as a shift from an extensive to an intensive form of residential suburbanisation. Although housing construction did not extend significantly to other parts of metropolitan regions, the intensities of migration and housing construction are even higher, thus creating more concentrated development closer to regional centres.

\section{References}

Johnson B. E., Shifferd J. Who lives where: A comprehensive population taxonomy of cities, suburbs, exurbs, and rural areas in the United States // The Geographical Bulletin. - 2016. - № 57. - P. 25-40.

Kok H., Kovács Z. The Process of Suburbanization in the Agglomeration of Budapest // Netherlands Journal of Housing and the Built Environment. - 1999. № 14. - P. 119-141.

Krišjāne Z., Bērzinšs M. Post-socialist Urban Trends: New Patterns and Motivations for Migration in the Suburban Areas of Riga, Latvia // Urban Studies. 2012. - № 49. - P. 289-306.

Nuissl H., Rink D. The "Production" of Urban Sprawl in Eastern Germany as a Phenomenon of Post-socialist Transformation // Cities. - 2005. - № 22. - P. 123134.

Ouředníček M. Differential Suburban Development in the Prague Urban Region // Geografiska Annaler: Human Geography. - 2007. - № 89B. - P. 111-125.

Špačková P., Ouředníček M. Spinning the Web: New Social Contacts of Prague's Suburbanites // Cities. - 2012. - № 29. - P. 341-349.

Ouředníček M., Špačková P., Klsák A. Zóny rezidenční suburbanizace v obcích Česka 2016: specialised map / Prague, Charles University, Faculty of Science, URRlab. http://www.atlasobyvatelstva.cz/cs/zony-2016. 